\title{
A EDUCAÇÃO CARTOGRÁFICA: DESAFIOS E LACUNAS NO ENSINO E APRENDIZAGEM1
}

Rafaela Gonçalves2

UEFS

Marcelo Faria3

DEDU

PALAVRAS-CHAVE: Ensino de Geografia; Educação Cartográfica; Espaço Geográfico.

\section{INTRODUÇÃO}

Para que a cartografia seja, de fato, utilizada pelos aos alunos da escola básica é necessário que se trabalhe focado em uma alfabetização cartográfica que permita aos estudantes ler e interpretar aspectos expressos em diferentes materiais cartográficos, e os utilize também para expressar suas interpretações de aspectos ligados à fenômenos espaciais, articulando os saberes de sala de aula com o contexto social, isto é, com "aquilo" que hoje ainda figura como uma exterioridade das discussões geográficas da escola básica.

Compreender a cartografia escolar como linguagem e, portanto, como possibilidade de expressão de conhecimentos dos estudantes acerca de questões espaciais, amplia bastante seu escopo, especialmente quando se ultrapassa o entendimento da cartografia como representação da realidade, expressa nos "mapas oficiais". A visão dominante da cartografia nas escolas é aquela das representações de áreas - vistas a partir de cima - nas quais os objetos espaciais - sua composição e arranjo - aparecem representados em formas, linhas e cores que definem um discurso que organiza o espaço. Há, no entanto, outras possibilidades de se expressar os fenômenos espaciais, outras leituras e escritas, que serão abordadas mais à frente.

Tomando como referência as noções de alfabetização cartográfica e mapeamento consciente (Simielli, 1999), e os estudos que advogam uma posição favorável ao ensino do espaço desde as séries iniciais com as "leituras de mundo" (Callai, 2005) propomos estudar as perspectivas do estudo do espaço através da cartografia nas séries iniciais do Ensino Fundamental em relação com as formas alternativas de leitura e escrita do espaço, na fronteira com o espaço vivido e com diferentes formas de expressão dos fenômenos no espaço.

\section{MATERIAL E MÉTODOS OU METODOLOGIA (ou equivalente)}

Para o desenvolvimento desta proposta foi feito levantamento bibliográfico em materiais de referência acerca da temática - concepção, conteúdos e estratégias de trabalho - com especial ênfase na dificuldade de aprendizagem e ensino buscando meios para contribuições com alfabetização cartográfica escola básica.

\footnotetext{
1Relatório Final de Iniciação Cientifica.

2 Graduanda em Licenciatura em Geografia pela Universidade Estadual de Feira de Santana, bolsista PROBIC/UEFS. Endereço eletrônico: raffaelasg@gmail.com

3 Prof $^{a}$. Dr. Marcelo Oliveira de Faria do Departamento de Educação da Universidade Estadual de Feira de Santana. Endereço eletrônico marcelo.faria65@gmail.com
} 
Análise de materiais levantados pela bolsista sobre e o assunto, verificação dos possíveis fatores que condicionam as dificuldades de ensino e aprendizagem na cartografia e pensar possibilidades de melhorar o quadro de dificuldade relacionado à alfabetização cartográfica a partir das analise.

Buscamos desenvolver maneiras de trabalhar a educação cartográfica, objetivando melhorar a qualidade da alfabetização cartográfica como a criação de materiais que possa contribuir para alfabetização cartográfica junto a profissionais de uma escola do município de Feira de Santana. Ao longo do trabalho busquei sempre realçar a importância da cartografia como linguagem para o ensino de Geografia.

\section{RESULTADOS E/OU DISCUSSÃO (ou Análise e discussão dos resultados)}

Com base nas leituras realizadas até o presente momento e os dados obtido no trabalho anterior desenvolvido (Gonçalves: 2017)4, percebemos que existe uma relação de conteudista realçada pelo ensino oficia da cartografia. Com isso conseguimos perceber algumas lacunas e desafios existente no ensino de geografia, em que buscamos formas possíveis de ensino da Cartografia para sanar ou minimiza-las.

Nosso esforço estar em apresentar uma cartografia que permite alcançar horizontes diversos e que contribua para a criação de uma educação que está permanentemente em construção e busca a atualização dos conhecimentos já existe as realidades atuais dentro de suas possibilidades. Apresentamos uma cartografia que não é unicamente acadêmica e técnica, mas que incorpore em sua produção elementos da arte e de sentido social, abrindo múltiplas possibilidades de expressão dos fenômenos espaciais, redefinindo, no limite, a interação dos professores e alunos.

Propomos a partir dos resultados obtidos na pesquisa, de modo a contribuir com o processo de alfabetização cartográfica e educação cartográfica para município de Feira de Santa, outras alternativas cartográficas, com desenhos narrativos,cartografando sentimento e outras.

\section{CONSIDERAÇÕES FINAIS (ou Conclusão)}

Concluímos que a cartografia é uma saber secular e elementar para a Geografia, considerando seu caráter de mediadora para facilitar a compreensão dos conteúdos

4 Gonçalves, R. S. Cartografia Escolar: Do Livro Didático À Educação Cartográfica. Feira de Santana-Ba: UEFS, 2017. 
geográficos. Pensando em sua importância acreditando que mesmo com os vários esquivos existente no seu ensino, é possível minimizar estas lacunas existentes.

É possível, e necessário compreender a cartografia como linguagem e não apenas conteúdo, pois dessa forma podemos pensar diversos projetos de ensino de geografia utilizando a cartografia para além de sua versão oficial.

0s resultados obtidos ao longo desta pesquisa são alternativas que podem ajudar a evidenciar a importância da cartografia no ambiente educacional, para compreensão do espaço local, evidenciar outros meios de trabalhar o "infinito" universo de possibilidades da Cartografia. Tanto como colocar o aluno no papel de produtor de saberes e matérias cartográficos.

Esperamos ter contribuído com as propostas de ensino da cartografia no processo de alfabetização cartográfica, na proposta de educação cartográfica para Feira de Santana.

\section{REFERÊNCIAS}

BRITO, Francisco Jorge de Oliveira; HETKOWSKI, Tânia Maria. Convergência cartográfica: mapas, mídias e jogos-simuladores. In: HETKOWSKI, Tânia Maria; ALVES, Lynn Rosalina Gama. Tecnologia digitais e educação: novas (re)configurações técnicas, sociais e espaciais. Salvador: Eduneb, 2011. p.115-137. CAVALCANTI. L. S. Cotidiano, Mediação Pedagógica E Formação De Conceitos: Uma Contribuição De VYGOTSKY Ao Ensino De Geografia. Campinas: Cad. Cedes, vol. 25, n. 66, p. 185-207, 2005.

SIMIELLI. M. E. R. Cartografia e Ensino de Geografia. São Paulo: USP, 1996. FREIRE, Paulo. Pedagogia do oprimido. 17. ed. Rio de Janeiro: PAZ E TERRA, 1987. 